\title{
Do we know how plants sense a drying soil?
}

\author{
Será que sabemos como as plantas detectam \\ o secamento do solo?
}

Nereu Augusto Streck ${ }^{1}$

\section{- NOTA -}

\section{ABSTRACT}

The reduction of crop growth and yield in dry areas is largely due to stomatal closure in response to dry soil, which decreases photosynthesis. However, the mechanism that causes stomatal closure in a drying soil is a controversial issue. Experienced and respected plant physiologists around the world have different views about the primary sensor of soil water shortage in plants. The goal of this review is to present a chronological synthesis about the evidence of the possible candidates for the mechanism by which plants sense a drying soil. Hydraulic signals in the leaves as the mechanism that causes stomatal closure dominated the view on how plants sense a drying soil during the 70's and the early 80's. In the middle 80's, studies suggested that stomatal conductance is better correlated with soil and root water status than with leaf water status. Thus, chemical signals produced in the roots dominated the view on how plants sense a drying soil during the late 80's and early 90's. During the second half of the 90's, however, studies provided evidence that hydraulic signals in the leaves are still better candidates for the mechanism by which plants sense a drying soil. After more than 60 years of studies in plant-water relations, the question raised in the title still has no unanimous answer. This controversial issue is a good research rationale for the current generation of plant physiologists.

Key words: soil water, plant water, water stress, stomatal conductance.

\section{RESUMO}

A redução do crescimento e as perdas de rendimento das culturas verificadas em áreas secas é, em grande parte, devido ao fechamento estomático em resposta ao solo seco, o que resulta em redução da fotosíntese. No entanto, o mecanismo que causa o fechamento estomático durante o secamento do solo é um assunto em debate. Fitofisiologistas conhecidos e respeitados em nível mundial têm visão diferente a respeito do sensor primário das plantas para detectar a diminuição do conteúdo de água no solo.
Neste estudo, é apresentada uma síntese cronológica das evidências a respeito de sinais hidráulicos nas folhas e sinais químicos nas raízes como mecanismos que a planta usa para detectar o secamento do solo. Sinais hidráulicos nas folhas dominou a visão da comunidade científica de como as plantas detectam o secamento do solo durante os anos 70 e início dos anos 80. Na segunda metade dos anos 80 e primeira metade dos anos 90, sinais químicos produzidos nas raízes foram tidos como os sinais com os quais as plantas detectam o secamento do solo. Na segunda metade da década de 90, no entanto, estudos mostraram que sinais hidráulicos produzidos nas folhas ainda seriam o mecanismo mais appropriado que a planta usa para detectar o secamento do solo. Após mais de 60 anos de estudos da relação planta-água, a pergunta que faz parte do título deste artigo ainda não tem uma resposta unânime.

Palavras-chave: água no solo, água na planta, estresse hídrico, condutância estomática.

\section{INTRODUCTION}

Soil water shortage is the environmental factor most limiting for crop growth and yield in most parts of the world (BOYER, 1982). Drought-related reduction of crop growth and yield is largely due to stomatal closure in response to low soil water content, which decreases the intake of $\mathrm{CO}_{2}$ and, consequently, decreases photosynthesis (WONG et al., 1985; JONES, 1992; ANTOLIN \& SANCHEZ-DIAZ, 1993). Therefore, the knowledge and an understanding of the mechanism by which plants sense the soil moisture depletion is important from a scientific point of view as well as for practical applications such as irrigation management, crop simulation models, and crop genetic improvement for drought tolerance.

\footnotetext{
${ }^{1}$ Engenheiro Agrônomo, PhD., Professor Adjunto, Departamento de Fitotecnia, Centro de Ciências Rurais, Universidade Federal de Santa Maria, 97105-900, Santa Maria, RS, Brasil. E-mail: nstreck1@ smail.ufsm.br
} 
It will be shown in this review that during the last century, many researchers around the world have dedicated a considerable amount of time of their life in trying to understand how plants sense a drying soil. However, despite decades of intense and fruitful study, the mechanism that causes stomatal closure in a drying soil is a controversial issue and the subject of vigorous debates (KRAMER, 1988; PASSIOURA, 1988a; BOYER, 1989). The objective of this review is to present a chronological synthesis about the evidence of the possible candidates for the mechanism by which plants sense a drying soil. Very detailed reviews about some of the mechanisms presented here are out of the scope of this paper and, if of interest, can be found elsewhere (e.g. DAVIES \& ZHANG, 1991).

\section{THE POSSIBLE MECHANISMS BY WHICH PLANTS SENSE A DRYING SOIL}

In the field of plant-water relations, the emphasis moved from measurements of soil water status to measurements of plant water status more than 60 years ago (KRAMER, 1937). It was recognized more than 50 years ago that stomatal closure is an effective mechanism to increase the resistance of water flow out of the plant (van der HONERT, 1948), and a possible negative feedback loop between stomatal conductance and leaf water potential was proposed almost 40 years ago (COWAN, 1965). Several studies after these initial efforts showed that, in the field, leaf water potential is usually the lowest in the plant, and that shoot water stress develops before a considerable root water stress develops (e.g. HUCK et al., 1970; SHARP \& DAVIES, 1979; WESTGATE \& BOYER, 1985). These results supported the assumption that hydraulic signals in the leaves are the mechanism that causes stomatal closure in response to a drying soil. Hydraulic signals originated in the leaves dominated the view on how plants sense a drying soil during the 70's and the early 80's (RASCHKE, 1975; KRAMER, 1983;ZEIGER, 1983).

In the middle 80's, studies suggested that stomatal conductance is better correlated with soil and root water status than with leaf water status (e.g. TERMAAT et al., 1985; SCHULZE, 1986a,b). Two approaches were used in the studies that changed the view on how plants sense a drying soil. One approach consisted of splitting roots into two containers and applying a low soil water treatment in one of the containers (BLACKMAN \& DAVIES, 1985; TERMAAT et al., 1985; ZHANG et al., 1987; SAAD \& SHARP, 1989). In this approach, part of the root system was kept in dry soil and part in wet soil, but plants were still able to take up sufficient water to maintain leaf water potential as high as in the control plants, which had their entire root system in wet soil. The other approach consisted of pressurizing the root system while keeping the soil dry or the root media salinity high, so that shoot was kept turgid irrespective of the water potential in the root media (GOLLAN et al., 1986; MUNNS, 1987; PASSIOURA,1988b). These two approaches allowed to break the interdependence of water status of roots and shoots. KRAMER (1988) heavily criticized these two approaches, and consequently the results from these studies, arguing that these two approaches are a laboratory artifact with little application to the real world, as in the field, shoots are exposed to dehydration first than roots, and therefore, leaves experience water deficiency before roots. PASSIOURA (1988a), on the other hand, replied to KRAMER's criticism arguing that, in the field, the topsoil indeed often dries out to much lower water potentials than the leaves may ever experience.

Apart from the criticism about the real value of the two approaches used to break the interdependence of water status of roots and shoots, the results from these experiments were appealing and showed that both leaf growth and stomatal conductance are largely unaffected by whether or not the leaves are kept turgid, but are indeed affected by the conditions in the root media. Chemical signals, especially abscisic acid (ABA), originated in the roots and transported to the leaves via the transpiration stream were assigned to be the signal that communicates the leaves with the roots (ZHANG et al., 1987; DAVIES \& ZHANG, 1991). Consequently, the traditional view of leaf water potential as a measure of water stress in plants (i.e. hydraulic signals) was proposed to be abandoned (SINCLAIR \& LUDLOW, 1985; PASSIOURA, 1988a), and chemical signals produced in the roots dominated the view on how plants sense a drying soil during the late 80's and early 90's (ZHANG \& DAVIES, 1989; DAVIES \& ZHANG, 1991; DAVIES et al., 1994). KRAMER (1988) criticized this view arguing that, at that time, plant physiologists had spent 50 years of progress in the understanding of plant water relations by shifting emphasis away from the soil to the shoots, and now, plant physiologists would have to return the emphasis to the soil based on experiments that used approaches with little application to the real world. PASSIOURA (1988a) replied that this return would not be a circle, but a helix, as shoot water status is indeed important but its effects are often overridden by signals from the roots. 
During the second half of the 90's, another shift occurred in the way scientists think plants work in a drying soil, as studies provided evidence that hydraulic signals in the leaves are still better candidates for the mechanism by which plants sense a drying soil (SALIENDRA etal., 1995; FUCHS \& LIVINGSTON, 1996; COMSTOCK \& MENCUCCINI, 1998). These studies used a root pressurizing technique to manipulate leaf and shoot water potential, as in previous studies, and showed that stomatal closure due to water stress caused by different factors (including low soil water content) could be reversed by applying pressure to the roots. The authors of these publications argued that, there is a conflict between ABA produced in the roots as the signal for stomatal response to low soil water and the occurrence of cavitation in drought-stressed plants, which decreases the transport of ABA from the roots to the leaves. Therefore, it is evident that things were puzzled again with regard to the actual mechanism by which plants sense a drying soil.

The discrepancies in the results about the mechanism by which plants sense a drying soil reported more recently and the results reported in the 80's and early 90's might be, at least in part, due to the differences in response between herbaceous and woody plants, as the experiments supporting a stomatal response to roots water status were performed in herbaceous species (e.g. BLACKMAN \& DAVIES, 1985; TERMAAT et al., 1985; GOLLAN et al., 1986; SAAD \& SHARP, 1989), and the experiments supporting a stomatal response to leaves water status were in woody and semi-woody species (e.g. SALIENDRA et al., 1995; FUCHS \& LIVINGSTON, 1996; COMSTOCK \& MENCUCCINI, 1998). However, interestingly this argument has no support of a recent study by MATZNER \& COMSTOCK (2001) who assumed that stomata indeed respond to leaves water status leaves in a drying soil for an herbaceous species (Phaseolus vulgaris L.). Are these evidences for returning to an emphasis away from the soil and towards the shoot of the plant again? And if so, is the return a circle, or a helix, i.e., did we gain understanding? Or, was KRAMER (1988) right when he suggested that "we should heed the admonition of Ernst Mayr, that a good theory should not be abandoned because a flaw is found in it"? Who is right and who is wrong is not clear at this point. What is clear at this point is that the answer for these questions should be pursued, because we need them.

\section{CONCLUSION}

After more than 60 years of intense studies in plant-water relations, the question raised in the title still has no unanimous answer. Both hydraulic signals in the leaves and chemical signals from the roots are strong candidates for the mechanism by which plants sense a drying soil. Two of the most experienced and respected plant physiologist worldwide, Dr P.J. Kramer and Dr. J.B. Passioura, have opposite views about the primary plant sensor of soil water stress. This contradictory results indicate that our knowledge about the mechanism by which plants sense a drying soil is quite poor and represent a good research rationale for the current generation of plant physiologists. However, to be able to move a step further in order to deepen our understanding on how plants deal with soil water shortage, we may need new hypotheses for the research question in future projects. Because new hypotheses challenge our view about the world, the improvement in our understanding on how plants deal with soil water shortage may take some time, because, as always, the devil is in the details.

\section{ACKNOWLEDGMENTS}

The author thanks to the Conselho Nacional de Desenvolvimento Científico e Tecnológico (CNPq), of the Ministry for Science and Technology of Brazil, for financial support during this study.

\section{REFERENCES}

ANTOLIN, M.C.; SANCHEZ-DIAZ, D.M. Effects of temporary droughts on photosynthesis of alfalfa plants. Journal of Experimental Botany, Oxford, v.44, n.265, p.1341-1349, 1993.

BLACKMAN, P.G.; DAVIES, W.J. Root and shoot communication in maize plants of the effects of soil drying. Journal of Experimental Botany, Oxford, v.36, n.1, p.3948, 1985 .

BOYER, J.S. Plant productivity and environment. Science, Washington, v.218, n.4571, p.443-448, 1982.

BOYER, J.S. Water potential and plant metabolism: comments on Dr P.J. Kramer's article, 'Changing concepts regarding plant water relations', Volume 11, Number 7 pp. 565-568, and Dr J.B. Passioura's response, pp. 569-571. Plant, Cell and Environment, Oxford, v.12, n.2, p.213-216, 1989.

COMSTOCK, J.; MENCUCCINI, M. Control of stomatal conductance by leaf water potential in Hymenoclea salsola (T. \& G.), a desert subshrub. Plant, Cell and Environment, Oxford, v.21, n.10, p.1029-1038, 1998.

COWAN, I.R. Transport of water in the soil-plant-atmosphere system. Journal of Applied Ecology, Oxford, v.2, n.1, p.221-239, 1965.

DAVIES, W.J.; ZHANG, J. Root signals and the regulation of growth and development of plants in drying soil. Annual 
Review of Plant Physiology and Plant Molecular Biology, Palo Alto, v.42, n.1, p.55-76, 1991.

DAVIES, W.J.; TARDIEU, F.; TREJO, C.L. How do chemical signals work in plants that grow in drying soil? Plant Physiology, Bethesda, v.104, n.2, p.309-314, 1994.

FUCHS, E.E.; LIVINGSTON, N.J. Hydraulic control of stomatal conductance in Douglas fir [Pseudotsuga menziesii (Mirb.) Franco] and alder [Alnus rubra (Bong)] seedlings. Plant, Cell and Environment, Oxford, v.19, n.9, p.10911098, 1996.

GOLLAN, T.; PASSIOURA, J.B.; MUNNS, R. Soil water status affects stomatal conductance of fully turgid wheat and sunflower leaves. Australian Journal of Plant Physiology, Melbourne, v.13, n.4, p.459-464, 1986.

van der HONERT, T.H. Water transport in plants as a catenary process. Discussions of the Faraday Society, London, v.3, n.3-4, p.146-153, 1948

HUCK, M.J.; KLEPPER B.; TALYLOR, H.M. Diurnal variations in root diameter. Plant Physiology, Bethesda, v.45, n.4, p.529-530, 1970.

JONES, H.G. Plants and microclimate: A quantitative approach to environmental plant physiology. 2.ed. New York : Cambridge University, 1992. 428p.

KRAMER, P.J. The relationship between rate of transpiration and rate of water absorption. American Journal of Botany, London, v.24, n.1, p.10-15, 1937.

KRAMER, P.J. Water relations of plants. Orlando : Academic, 1983. 483p.

KRAMER, P.J. Changing concepts regarding plant water relations. Plant, Cell and Environment, Oxford, v.11, n.7, p.565-568, 1988.

MATZNER, S.; COMSTOCK, J. The temperature dependence of shoot hydraulic resistence: implications for stomatal behaviour and hydraulic limitation. Plant, Cell and Environment, Oxford, v.24, n.12, p.1299-1307, 2001.

MUNNS, R. Does leaf turgor determine leaf expansion rates in dry or saline soils? In: COSGROVE, D.J.; KNIEVEL, D.P. Physiology of cell expansion during plant growth. Rockville : The American Society of Plant Physiologists, 1987. p.241-242.

PASSIOURA, J.B. Response to Dr P.J. Kramer's article, 'Changing concepts regarding plant water relations', Volume 11, Number 7 pp. 565-568. Plant, Cell and Environment, Oxford, v.11, n.7, p.569-571, 1988a.

PASSIOURA, J.B. Root signals control leaf expansion in wheat seedlings growing in dry soil. Australian Journal of Plant Physiology, Oxford, v.15, n.5, p.687-693, 1988b.
RASCHKE, K. Stomatal action. Annual Review of Plant Physiology, Palo Alto, v.26, n.1, p.309-340, 1975.

SAAD, I.N.; SHARP, R.E. Non-hydraulic signals from maize roots in drying soil: inhibition of leaf elongation but not stomatal conductance. Planta, Berlin, v.179, n.4, p.466474, 1989.

SALIENDRA, N.Z.; SPERRY, J.S.; COMSTOCK, J.P. Influence of leaf water status on stomatal response to humidity, hydraulic conductance, and soil drought in Betula occidentalis. Planta, Berlin, v.196, n.2, p.357366, 1995.

SCHULZE, E.D. Carbon dioxide and water vapour exchange in response to drought in the atmosphere and in the soil. Annual Review of Plant Physiology, Palo Alto, v.37, n.1, p.247-274, 1986a.

SCHULZE, E.D. Whole-plant response to drought. Australian Journal of Plant Physiology, Melbourne, v.13, n.2, p.127-141, 1986 b.

SHARP, R.E.; DAVIES, W.J. Solute regulation and growth by roots and shoots of water-stressed maize plants. Planta, Berlin, v.147, n.1, p.43-49, 1979.

SINCLAIR, T.R.; LUDLOW, M.M. Who taught plants thermodynamics? The unfilled potential of plant water potential. Australian Journal of Plant Physiology, Melbourne, v.12, n.3, p.213-217, 1985.

TERMAAT, A.; PASSIOURA, J.B.; MUNNS, R. Shoot turgor does not limit growth of NaCl-affected wheat and barley. Plant Physiology, Bethesda, v.77, n.7, p.869-872, 1985.

WESTGATE, M.E.; BOYER, J.S. Osmotic adjustment and the inhibition of leaf, root, stem, and silk growth at lower water potentials in maize. Planta, Berlin, v.164, n.4, p.540549, 1985.

WONG, S.C.; COWAN, I.R.; FARQUHAR, G.D. Leaf conductance in relation to rate of $\mathrm{CO}$ assimilation. III. Influence of water stress and photoinhibition. Plant Physiology, Bethesda, v.78, n.4, p.830-834, 1985 .

ZEIGER, E. The biology of stomatal guard cells. Annual Review of Plant Physiology, Palo Alto, v.34, n.1, p.441475,1983

ZHANG, J.; SCHURR, U.; DAVIES, W.J. Control of stomatal behaviour by abscisic acid which apparently originates in the roots. Journal of Experimental Botany, Oxford, v.38, n.192, p.1174-1181, 1987.

ZHANG, J.; DAVIES, W.J. Abscisic acid produced in dehydrating roots may enable the plant to measure the water status of the soil. Plant, Cell and Environment, Oxford, v.12, n.1, p.73-81, 1989. 